Annals of Warsaw University of Life Sciences - SGGW

Land Reclamation No 39, 2008: 139-150

(Ann. Warsaw Univ. of Life Sci. - SGGW, Land Reclam. 39, 2008)

\title{
Land use - land cover change of Służewiecki Stream basin and theirs hydrological consequences
}

\author{
MONIKA OKSIUTA, MAŁGORZATA GUTRY-KORYCKA \\ Department of Hydrology, Faculty of Geography and Regional Studies, University of Warsaw
}

\begin{abstract}
Land use - land cover change of Stużewiecki Stream basin and theirs hydrological consequences. The basin of the Stużewiecki Stream, hydrologically uncontrolled, is urbanised, but it has a mosaic-like character, consisting of urban and agricultural land use. This is shown by the graph of the basin and its subcatchments that takes into account the changes of the runoff coefficient in its subcatchments. The land cover changes in 1993-2002 and the forecast for the years until 2012, together with the calculated rainfall hyetograph are input elements to the rainfall-runoff model. The isochrone method with the Kirpich equation constitute the transforming function, and the runoff hyetographs are the output elements from the system. The paper presents also practical problems occurring in the implementation of the recommendations of the local spatial plan as well as consequences resulting from disregarding the recommendations.
\end{abstract}

Key words: urban impact, design storm hyetograph, hydrograph, runoff coefficient.

\section{INTRODUCTION}

Changes of the hydrological system, especially those occurring under the influence of urbanization, have scientific and practical aspects related to forecasting, prevention, and minimization of their consequences. High-intensity rain occurs more and more often in the Warsaw metropolitan area; an example of this is the Służewiecki Stream. After intensive rains, water overflows the riverbed, inundates or floods the nearby housing estates in the Arbuzowa Street, localized in the lower part of the basin. Another often-flooded part of the basin is located below the Arbuzowa Street estate, in Wilanów. For many decades, the area had been formed as ecologically valuable and extensively utilized meadows, which were well suited to be polders. Nowadays, however, a large complex of housing estates is being built there: the Wilanów Village.

In the basin of the Służewiecki Stream, the degree of urbanization is increasing. By the degree of urbanization the authors mean the share of the intensely developed impermeable surfaces. The intense development had begun in the years 1918-1939, when the Okęcie Airport was built. Reconstruction of the districts of Rakowiec and Upper Mokotów after the II World War changed the upper part of the basin. The development continued: many industrial plants (Industrial Służewiec), as well as the housing estate Służewiec for 26 thousand of people had been built. The most intensive period of urbanization of this area took place, however, in the 1970s and 1980s; it was 
related to the construction of the housing estate Ursynów-Natolin for 150 thousand of people (Łyszka 2000). The beginning of the 21 st century is characterized by an even greater density of the high-rise buildings of Ursynów and Wilanów; the first stage of their construction was completed in 2007.

Anthropogenic changes of area are decrease of the basin. The course of the Służewiecki Stream was also changed, and stormwater drainage was included in its river system. Contemporary trends consist in the further change of the land use character and in the expansion of the underground drainage system which channels rain and melt water.

\section{LOCALIZATION OF THE BASIN AND AIMS OF THE STUDY}

The Służewiecki Stream is a third-degree watercourse, which flows into the Wilanówka river, a left-side tributary of the Vistula river. The stream drains the southwestern districts of Warsaw. Its length is ca. $15 \mathrm{~km}$ and the surface area of its topographic basin is $55 \mathrm{~km}^{2}$ (Banasik 2002) or according to earlier data, it was changing between 53 and $58 \mathrm{~km}^{2}$ (Nowicka 2002). This was a result of the unclear course of the watershed in its southern part. Distinct borders of the topographic basin are delimited by the range of the stormwater drainage (Fig. 1).

Explanations:

1-18 number

of subbasin
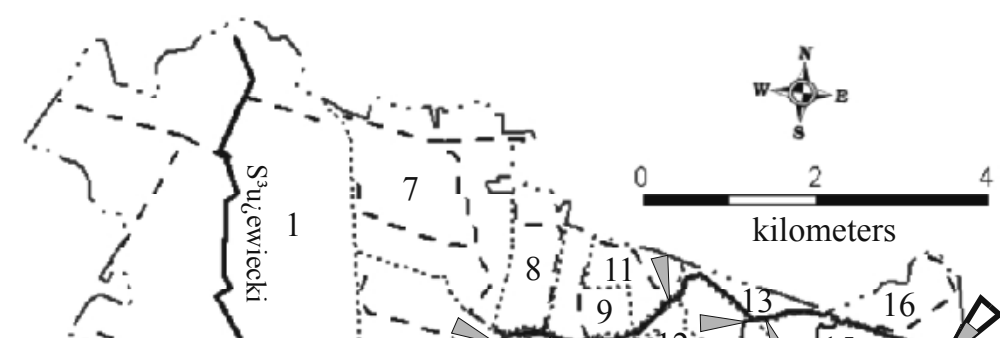

$1:-21-7$

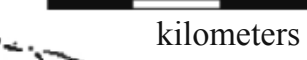

surface net of quasi-

natural streams

_ _ subsurface net of

periodical outflow

_.... topographical water

divide III order

uncertain water

divide of subbasins

I I I I uncertain water divide

subbasins periodical outfall gauges

basin outfall gauges

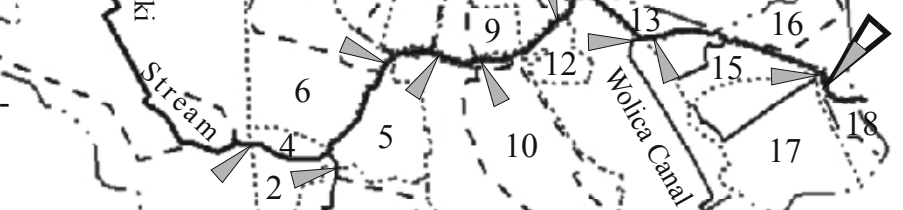

FIGURE 1. Watersheds of urban Służewiecki Stream basin 
The paper aims at the estimation of the changes of the high-water runoff of the Służewiecki Stream in 1993-2012. The estimation is based on the differences in the management state of the basin in the decade 1993-2002 and a forecast for 2012 , because they are the "variable" operator of the urbanized system in the simplest rainfall-runoff model. It is also important to verify the usability of the classic method of isochrone in determining of the hydrograph of the runoff caused by a given rainfall in urban basins. Additionally, a study of the spatial structure of the runoff and the role of the hydrographical nodes in the storm-water drainage system has been made. For this purpose, a modified graph, called the basin expansion, was used. Measurements were also conducted whose aim was to estimate the runoff of the basin under various hydrometeorological conditions, by means of the longitudinal profile of the simultaneous runoff from the basin (Oksiuta 2007a).

\section{LAND USE - LAND COVER CHANGE (1993-2002)}

Changes during utilization makes possible the detection of a specific reaction of the basin to the supply. Due to the lack of detailed maps of the basin in the scale 1:10 000 from before 1993 as well as to the heterogeneity of their reference systems, the analysis of land use maps is imprecise and nonuniform. For that reason, it was decided to apply a comparative analysis of the management changes of the Służewiecki Stream basin to the period as late as 1993-2002.

For the purpose of identification of the management state of the Służewiecki
Stream basin, the Land Use Map... (2002) in the scale 1:10 000 was used; it was made in the cartographic system 1992, and used for planning. 140 forms of land use and their scope were distinguished on the map. By aggregation according to the criterion of morphological similarity and that of the similar share of impermeable and weakly permeable surfaces, the number of forms was reduced to 17 (Fig. 2). Runoff coefficients were assigned to the forms (Bedient and Huber 1989; Radwan-Dębski 1995), as shown in Figure 3. As mentioned before, the management state in 1993 was identified from the topographic maps in the scale 1:10 000 made in the 1992 system, and therefore their geodetic conversion with respect to the state of 2002 was not necessary. It was assumed that the kind and range of the development in 1993 did not change with respect to 2002 . Therefore, it was sufficient to reconstruct the land use type existing before the development of the decade 1993-2002 from topographic maps. This was mostly agricultural lands, allotment gardens, parks, and wasteland (Oksiuta 2006).

In 1993-2002 changes of the agricultural land use occurred in eight subcatchments, of which four were of small surface $(<5 \mathrm{ha})$. In the remaining catchment areas the changes of land use did not exceed $1 \mathrm{~km}^{2}$; the largest changes occurred in the basin of the Wolicki canal (14). The surface area of agricultural land and of allotment gardens decreased by 100 ha (13\%), while the area of housing development $>12 \mathrm{~m}$ above ground level increased, as did the area of service facilities and of detached housing. The wasteland area remained the same, but the former farmland had been used for 

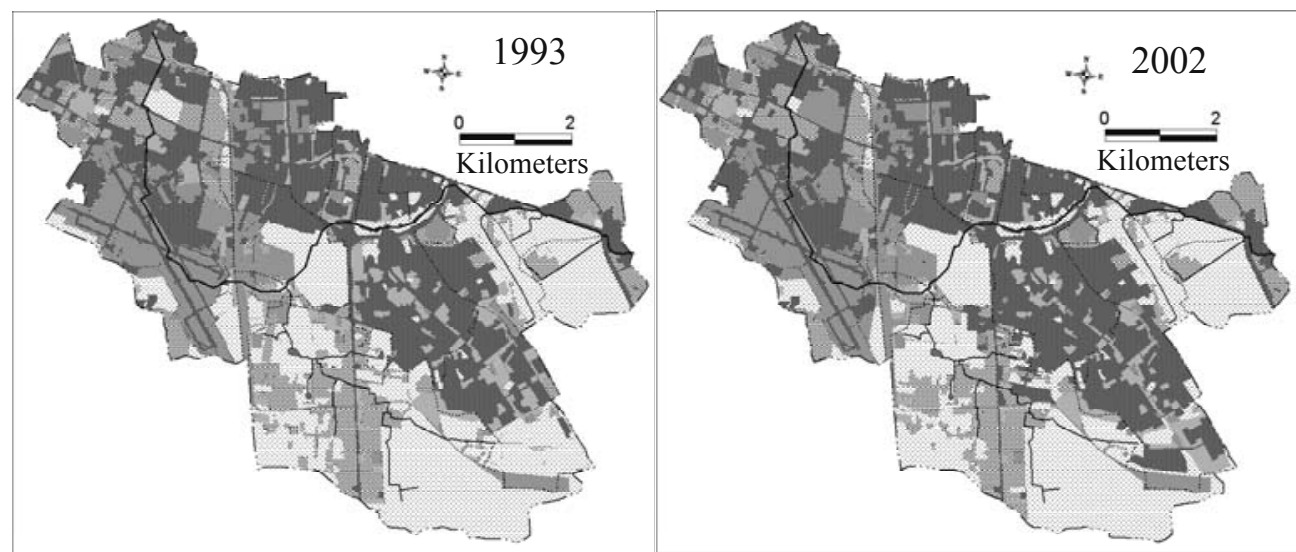

Explanations:
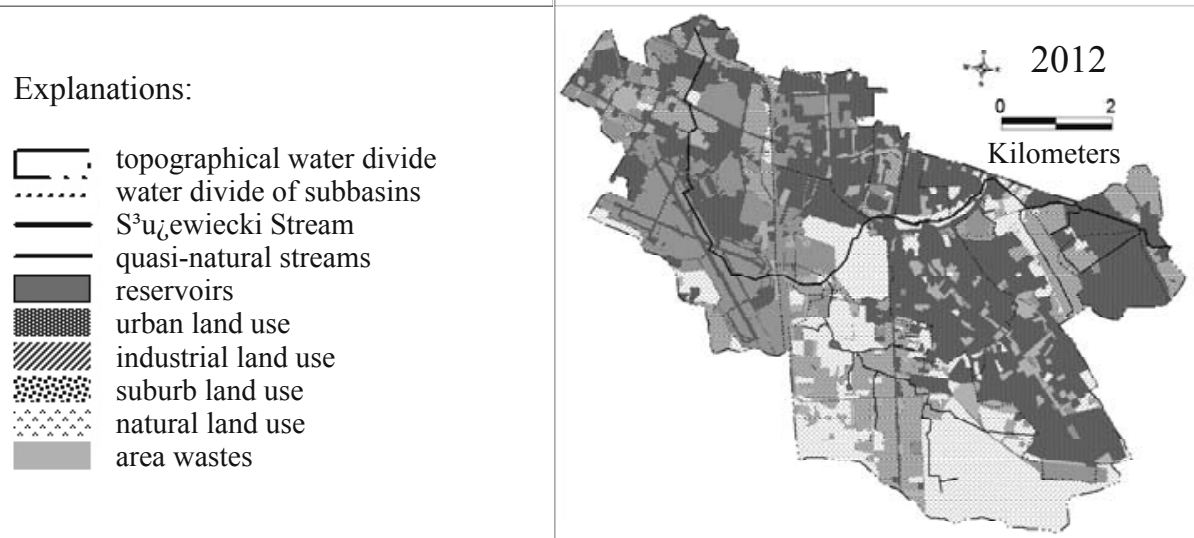

FIGURE 2. Change of land use in Służewiecki Stream basin in 1993, 2002, 2012 year

housing development. The significant changes (75 ha) which occurred in the Okęcie catchment $(1)^{1}$ were related to the use of wasteland and green areas for facilities and for the paved surface of the airport. The largest changes of the Grabowski Ditch basin (3) (65 ha) were caused by the construction of service facilities - the hypermarket West Ursynów. Moreover, the areas of five types of housing development were increased, in particular those of detached housing with backyards and gardens. In the Ursynowski canal basin (10), the density

\footnotetext{
${ }^{1}$ The numbers of the subcatchments are marked in Figure 1.
}

of the development was also gradually increasing, in particular that of housing development.

In the period 1993-2002, the greatest changes of land use occurred in the upper and middle parts of the Służewiecki Stream basin. The changes in the lower, high-plain part of the Wolicki canal basin (14) were not significant, but the largest changes occurred in Ursynów, due to the construction of the underground railway and its base.

Land use character is still mosaic-like, and land fragmentation results in heterogeneity of the runoff from subcatchments (Figs 2,3). The basin expansion shows an 


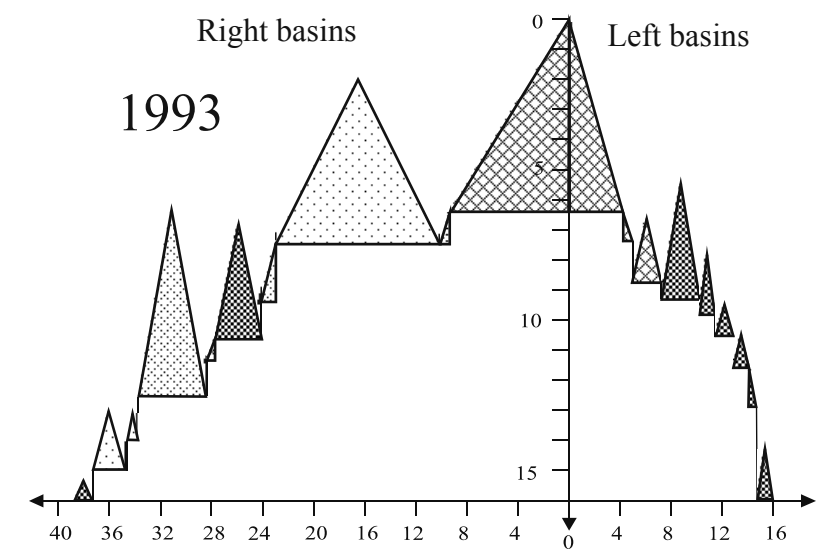

Runoff coefficient:
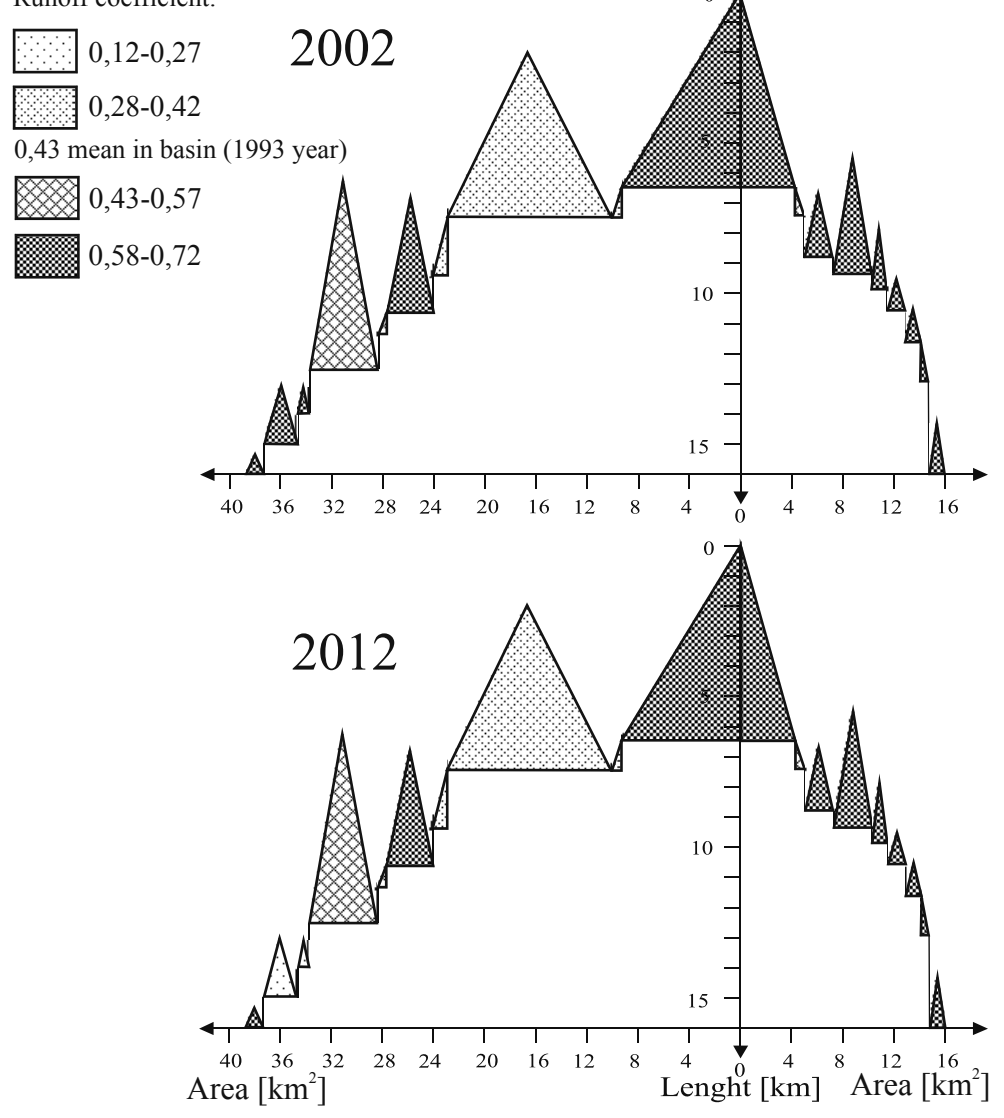

FIGURE 3. Growth of area basin and length of streams in Służewiecki Stream (1993, 2002, 2012) 
asymmetry of the drainage field, despite of the same number of right-side and left-side tributaries. The right part of the basin $\left(39 \mathrm{~km}^{2}\right)$ is over twice as large as the left part $\left(16 \mathrm{~km}^{2}\right)$, but the left one is more intensely developed, which is conducive to the increase of rain runoff coefficient ( $>60 \%$ ). The right part of the basin is, on the other hand, more varied, and consists of strongly and weakly developed subcatchments (Oksiuta 2007b).

The most important hydrographical node is the confluence of the Ursynowski canal (10) (a right tributary) and the Bach Street collector (9) (a left tributary) in the Służewiecka Little Valley (Fig. 3), which drains intensely the housing districts of Ursynów and Służewiec. Another important drainage node is the confluence of the Wolicki canal (14), which collects water from the strongly developed catchment area $\left(\mathrm{ca} 8 \mathrm{~km}^{2}\right)$. All the significant changes in management in the period 1993-2002 affected subcatchments on the right-hand side of the stream.

\section{PROGNOSIS OF LAND COVER CHANGE (2012)}

The map of the future (2012) state of the management of the Służewiecki Stream basin (Fig. 2) was made on the basis of the Land Use Map... (2002), updated with help of the local plans of spatial management of the Wilanów district (Dz. Urz. Woj. Maz. nr 47, 2001; Dz. Urz. Woj. Maz. nr 52, 2001). Areas not taken into account by the local plans were completed by field charting of land use, marking those developments where construction has already started (Oksiuta 2006).
Inthe2002-2012decade, the direction of the planned changes in use is moving from the upper basin towards the lower basin. The changes will encompass five subcatchments, including the smallest ones: Okęcie (1) (30 ha) and the Grabowski Ditch (3) (60 ha). The largest transformations are planned in the basin of the Wolicki Ditch (17), and affect both the surface area (180 ha) and the share of the changed utilization (88\%). The agricultural lands will be used for service areas and housing estates $>12 \mathrm{~m}$ above ground level. Detached housing development and service facilities for public transport will take only insignificant fragments. In the Wolicki canal basin (14) as much as 140 ha of agricultural land and wasteland will be used for housing development, especially for detached housing. In the catchment of the segment of the Służewiecki Stream near the Arbuzowa and Przyczółkowa streets (15) over 70 ha of agricultural lands will be used by apartment houses of $12 \mathrm{~m}$ height, as well as by detached housing with backyards and gardens.

In the decade 2002-2012 the changes in utilization of the entire basin will continue. They consist in further transformation of wasteland into an area with high investment. Apart from the constantly increasing density of housing development, both multi-family and single-family, a large complex of housing estates is being created: the Wilanów Village. This will cause the closing of the open terrains in the lower part of the basins as a result of the development, which will move the bulk of land use changes from Ursynów to Wilanów. This will be the last change in use of such large spatial scope. 
Analysis of the transformations in the period 1993-2012 shows a clear and intense rate of urbanization. In the period 1993-2012 the changes in use will encompass over $10 \%$ of the area of the entire basin. If the rate of development remains the same, in 2050 the basin will become entirely urbanized.

\section{HYDROLOGICAL CONSEQUENCES OF LAND USE}

The sum and the intensity of precipitation as inputs into the runoff system of an urban catchment area form the basis for the estimation of hydrological reaction. The amount of the maximum rainfall measured at the Okęcie station and studied by Bogdanowicz and Stachy (1998), as the function of intensity and of the probability of surface runoff became the basis for the design hyetograph ${ }^{2}$, characterized by a constant time step and a symmetric shape with the maximum intensity in the middle time step (Bognanowicz 1998). In the case of the Służewiecki Stream basin, the one-hour time step was used for the calculation of rainfall. Intense rains of convective ( 3 hours) and expansive ( 8 hours) types were analysed.

An estimation of the high-water runoff from the analysed uncontrolled catchment undergoing urbanization depends on the degree of development in the basin. The identification of the rain runoff coefficient $(\alpha)$ can be used as a basis for the estimation of the runoff by means of the hyetograph of the effective rainfall. Such rainfall is quickly conducted to the

\footnotetext{
${ }^{2}$ A design hyetograph is a theoretical rainfall hyetograph with the most disadvantageous (high) runoff. It is used to calculate capacity of storm drainage (Bogdanowicz 1998).
}

main watercourse and causes a sudden increase in the flow rate (Banasik, Ignar 1986). The volume of the effective rainfall is not sufficient to calculate the high-water flow and the maximum flow. To determine the reaction of the basin to a given rainfall, the isochrone method with the Kirpich equation was used (after Chow, Maidment, Mays 1988), which allows to calculate the time needed to reach the closing profile from the watershed, according to the function:

$$
T c=\left(0.868 \cdot L^{3} / \Delta H\right)^{0.385}
$$

where:

$L$ - actual length from the node to the closing profile $[\mathrm{km}]$, $\Delta H$ - denivelation of the basin [m].

Hyetographs of the total ordinary ${ }^{3}$ rainfall of three and eight hours duration, after the method of Bogdanowicz (1998), are shown in Figure 4. A characteristic feature of the method is the assumption that the constant rainfall time step, independently of the number of the steps and of the duration of the rainfall. The almost symmetrical shape of the design hyetograph differs from the majority of hyetographs of actual rainfalls, in which the maximum occurs in the beginning phase of rainfall duration. This shape was, however, regarded as the least advantageous, and that's why it is applied to calculate the outflow from the storm drainage and of other drainage installations.

The hydrograph of the high-water runoff in the profile closing the basin of the Służewiecki Stream above the Palace Park in Wilanów is located near the Przyczółkowa Street, where the hydro-

\footnotetext{
${ }^{3}$ Ordinary rainfall is characterised by a $99 \%$ probability of occurrence, that is, it occurs statistically 99 times in 100 years.
} 

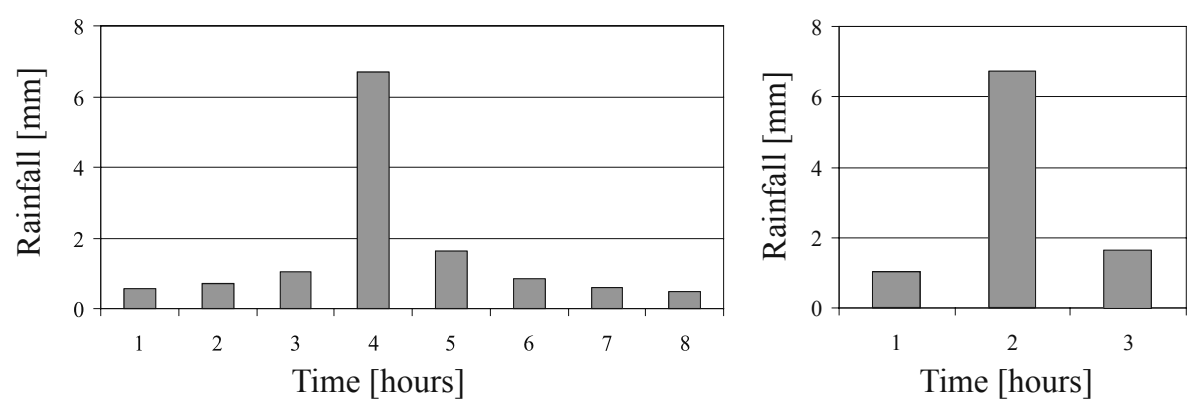

FIGURE 4. Design storm hyetogram in Służewiecki Stream basin, 1 year exceeding frequency, 3 and 8 hour duration calculated according to Bogdanowicz method (1998). Maksimum total rainfall calculated according to Bogdanowicz and Stachy method (1998)
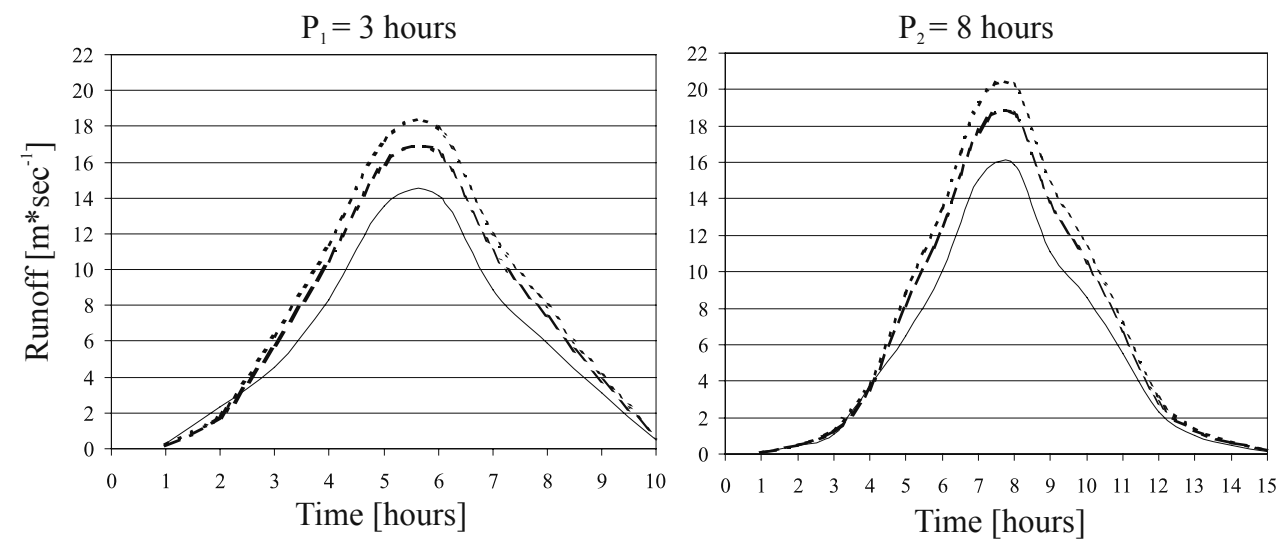

Hydrograph $1993 \quad$ - - Hydrograph 2002

- - - Hydrograph 2012

FIGURE 5. Służewiecki Stream runoff hydrographs in response to rainfall of 1 year exceedings frequency, $3\left(\mathrm{P}_{1}\right)$ and $8\left(\mathrm{P}_{2}\right)$ hours duration for different land-use in the basin

metric profile of the SGGW is also located. Since there are no tributaries between the two profiles, it is possible to compare the results obtained. Simplified calculations do not take into account the transformation of the high-water flow in the riverbed. Because of that, the shape of the analysed runoff hydrographs is similar (Fig. 5). The maximal flow, caused by a three-hour rainfall, is ca $14-18 \mathrm{~m}^{3} / \mathrm{sec}$. During 20 years urbanization will cause an increase of the maximal flow by ca
$4 \mathrm{~m}^{3} / \mathrm{sec}$, that is by $26 \%$. A similar reaction of the basin to the high-intensity rainfall lasting eight hours shapes the high-water wave with the maximal flow of ca 16-20 $\mathrm{m}^{3} / \mathrm{sec}$, depending on the state of basin urbanization. In the second variant of the calculations the increase of the maximal flow rate is also ca $4 \mathrm{~m}^{3} / \mathrm{sec}(25 \%)$, which shows that the difference of flow effected by rainfall of various durations is small. The shape of the hydrograph of flow caused by the three-hour rainfall 
is flatter and lower than that of the flow caused by the eight-hour rainfall. This follows from the specific feature of the isochrone method: a characteristic feature of the method is that the largest flow is reached at the moment when water from the entire area of the basin's surface flows into the closing profile. Such situation occurs precisely during a longer rainfall. During a three-hour rainfall, when water from a part of the basin flows into the closing profile, the hydrograph of the runoff is flatter. In the case of an eight-hour rainfall, the maximum flow in all three management states occurs at the same time (ca 7 hours $45 \mathrm{~min}$.) and is equal to the time that it takes for water to flow in from the farthest end of the basin. When the rainfall lasts three hours, the time of the occurrence of the maximum flow changes and depends on the degree of basin management. In the case under investigation, the maximal flow is delayed.

The calculated maximum flow is very high, and that is why the results obtained have been compared with the calculations of Banasik (2002) and Banasik et al. (2007). In the case of runoff with the $1 \%$ probability of occurrence, the calculated rate of flow is almost three times as large as the one obtained by Banasik (2002), who used the SCS method to calculate the effective rainfall and the Nash model to transform the effective rainfall into the high-water runoff. The most recent results of the runoff from the Służewiecki Stream basin indicate smaller differences between the results. The authors again used the SCS method to estimate the effective rainfall and the Nash model as the operator of the transforming function system. As the rainfall input, both the SGGW team and the authors of this paper, used the Bogdanowicz and Stachy method (1998). Comparison of the results is, however, not possible, because the SGGW team analysed two subcatchments: the upper one (Okęcie) and the middle one (Ursynów) with the total surface area of ca $39 \mathrm{~km}^{2}$, while in this study the entire basin (ca $55 \mathrm{~km}^{2}$ ) has been analysed. Moreover, in each study a different probability of the maximal rainfall excess was assumed: once in 10 years $(10 \%)$ in the study by Banasik et al. (2007) and once a year (99\%) in the authors' own study. The different results are caused by a different assumed rainfall duration and by taking into account one meteorological station (Warszawa-Okęcie in the authors' study) or two stations (Warszawa-Okęcie and Warszawa-SGGW Campus) when calculating its synthetic amounts. The runoff calculated by the SGGW team depending on the management state of the basin is lower (past state), similar (current state) and higher (future state), respectively, than the obtained by the authors. Moreover, the differences are caused also by the imperfection of the isochrone method (delineated manually) which assumes the rainfall in the entire basin as uniform. Although the urbanized basin under investigation is not large, the storm rainfall and the expansive rainfall with such spatial range do not occur often, and therefore the runoff should be lower than it had been calculated.

\section{LOCAL SPATIAL PLANNING - THEORY AND PRACTICE}

One of the tasks of spatial planning is to maintain order and harmony in the management of infrastructure space. An important element of this is the Study 
of Conditions and Directions of Spatial Management of the City of Warsaw (2006). The Study determines the planning policy of the capital city districts and coordinates the comprehensive planning of the city development. The Study is important in the creation of long-term investment plans, but it has no legal power; it performs an advisory function to the administrative decision-making regarding building permits. This is a very disadvantageous legal situation, because it allows to disregard the recommendations and guidelines contained in it (Study of Conditions..., 2006).

In the Study, terrains of great and medium importance for the creation of the City Natural System were distinguished. The System has a very strong impact on the level of comfort or nuisance of life in a great city. A considerable part of the Wilanów meadows should, according to the Study, form the core of the System; the core should be surrounded by somewhat less valuable areas. At the same time, a forecast of the transformations of natural conditions unambiguously shows that the housing estate Wilanów Village planned on the Wilanów meadows is particularly disadvantageous (Study of Conditions..., 2006). Unfortunately, the first part of this investment has already been completed, and its negative consequences, which are anyway hard to to be foreseen, will continue to effect their impact.

\section{CONCLUSIONS}

An approximate estimate of the rainfall - surface runoff from the ungauged urbanized basin and of its changes can be performed on the basis of a land use structure map. The identification of the amount of impermeability of an urbanized basin is not, however, sufficient to quantitatively estimate the runoff even at the planning stage. Only one category of land use (roads) can be uniquely classified as impermeable surfaces. In 1993-2012 their surface areas increased insignificantly and they constituted ca $11 \%$ of the basin. For this reason, the impermeability of the basin was estimated on the basis of the runoff coefficient (> 60\%). Surfaces defined as impermeable (roads included) in consequence constituted $46 \%$ of the basin in 1993, and as much as $51 \%$ in 2002. According to the forecast the impermeability of the basin will be $57 \%$ in 2012 . The absolute degree of basin urbanization is not high, but the concentration of intensely managed areas around the Służewiecki Stream speeds up the concentration of the runoff and increases the rate of maximum flow. The maximum flow values calculated here $\left(14-18 \mathrm{~m}^{3} / \mathrm{sec}\right.$ in a three-hour rainfall events and $16-20 \mathrm{~m}^{3} / \mathrm{sec}$ an eight-hour one) are only approximate.

The planning of a storm drainage system, and particularly of the dense development around the drainage network, should utilize a calibrated mathematical rainfall-runoff model. This enables the simulation of the changes in runoff conditions and for the determination of endangered zones, both direct and secondary, in which there is a hazard of flooding by the main watercourse during a high-intensity rain. Every mathematical model, however, close to perfection, must be supported by input data and by the current state of the basin development. The problem of the impact of urbanization remains open, and its solution is not possible without meteorological and hydrological monitoring. 


\section{REFERENCES}

BANASIK K. 2002: Operat hydrologiczny Potoku Służewieckiego w przekroju ul. Przyczółkowej, unpublished materials of SGGW, Warszawa.

BANASIK K., IGNAR S. 1986: Wpływ metody wyznaczania opadu efektywnego na parametry modelu Nasha małej zlewni rolniczej. Gosp. Wodna, 4, s. 81-86.

BANASIK K., HEJDUK A.L., BARSZCZ M. 2007: Current and Perspective Flood Flow Consequences of Land Use Changes in Slużew Creek (Suburb of Warsaw) [in:] Hamburger Wasserbau - Schriften, Special Aspects of Urban Flood Management, Proceedings Cost Session Aquaterra Conference 7-9/02/2007, s. 3-16.

BEDIENT P.B., HUBER W.C. 1989: Hydrology and floodplain analysis, Addison-Wesley \& Company, New York.

BOGDANOWICZ E. 1998: Czasowa i przestrzenna zmienność opadów maksymalnych, Tape scripts in the library of IMGW, Warszawa.

BOGDANOWICZ E., STACHY J. 1998: Maksymalne opady deszczu w Polsce. Charakterystyki projektowe, IMGW, Warszawa.

KIRPICH za CHOW V.T., MAIDMENT D.R., MAYS L.W. 1988: Applied Hydrology, McGraw-Hill.

Dziennik Urzędowy Województwa Mazowieckiego nr 47, 2001: Uchwała nr 404 Rady Gminy Warszawa-Wilanów z dnia 11 stycznia $2001 \mathrm{r}$. w sprawie uchwalenia miejscowego planu zagospodarowania przestrzennego terenów Przedpola Pałacu Wilanowskiego, Warszawa.

Dziennik Urzędowy Województwa Mazowieckiego nr 52, 2001: Uchwała nr 405 Rady Gminy Warszawa-Wilanów z dnia 18 stycznia $2001 \mathrm{r}$. w sprawie uchwalenia miejscowego planu zagospodarowania przestrzennego rejonu Wilanowa Zachodniego, Warszawa.

ŁYSZKA M. 2000: Przekształcenia przestrzeni Ursynowa w okresie transformacji. Manuscript of the M.Sc. thesis, archive of WGSR UW.

Mapa Użytkowania Gruntów, aktualizacja 2002 r., 2002, Miejska Pracownia Planowania Przestrzennego i Strategii Rozwoju, Warszawa. (Land Use Map, current version, 2002)

NOWICKA B. 2002: Wpływ urbanizacji na warunki odpływu. [w:] Obieg wody w zmieniającym się środowisku, Prace Instytutu Geografii AŚ w Kielcach, s. 77-85.
OKSIUTA M. 2006: Zmiany ustroju hydrologicznego Potoku Służewieckiego, Manuscript of M.Sc. thesis in Zakład Hydrologii WGiSR UW, Warszawa.

OKSIUTA M. 2007a: Odpływ w zlewni zurbanizowanej na przykładzie Potoku Służewieckiego w Warszawie [in:] Michalczyk Z. (red.) Obieg wody w środowisku naturalnym i przekształconym, Wydawnictwo Uniwersytetu Marii Curie-Skłodowskiej, Lublin.

OKSIUTA M. 2007b: Ocena odpływu wezbraniowego ze zlewni Potoku Służewieckiego w Warszawie, Prace i Studia Geograficzne, T. 38, Wydawnictwa Uniwersytetu Warszawskiego, Warszawa, s. 57-71.

RADWAN-DĘBSKI R. 1995: Szacunek opadu efektywnego na podstawie stopnia uszczelnienia terenu, Gosp. Wodna, 4, s. 77-80.

Studium uwarunkowań i kierunków zagospodarowania przestrzennego m. st. Warszawy, 2006, Miejska Pracownia Planowania Przestrzennego i Strategii Rozwoju, Warszawa. (Study of Conditions and Directions of Spatial Management of the City of Warsaw).

Streszczenie: Zmiany użytkowania ziemi w zlewni Potoku Stuzewieckiego i ich konsekwencje hydrologiczne. Niekontrolowana hydrologicznie zlewnia Potoku Służewieckiego o powierzchni zlewni wynoszącej $55 \mathrm{~km}^{2}$ jest w $51 \%$ zurbanizowana. Charakteryzuje się nadal mozaikową strukturą użytkowania miejskiego i rolniczego. Obrazuje to wykres trójkątny rozwinięcia zlewni (dopływy prawe i lewe) uwzględniający zmiany współczynnika odpływu w zlewniach cząstkowych. Zmiany użytkowania w latach 1993-2002 i ich prognoza do 2012 roku (z planu zagospodarowania przestrzennego) wraz $\mathrm{z}$ obliczonym metodą Bogdanowicz (1998) hietogramem opadu są elementami wejścia do modelu opad-odpływ. Metoda izochron połączona ze wzorem Kirpicha jest funkcją transformująca, a hydrogramy odpływu są elementami wyjścia z systemu. Zmiany użytkowania terenu w latach 1993-2012 obejmą 10\% powierzchni zlewni. Spowoduje to ok. $25 \%$ wzrost przepływu maksymalnego wywołanego opadem trwającym, zarówno 3 godziny $\left(14-18 \mathrm{~m}^{3} / \mathrm{s}\right)$, jak i 8 godzin $\left(16-20 \mathrm{~m}^{3} / \mathrm{s}\right)$.

MS. received April 2008 
150 M. Oksiuta, M. Gutry-Korycka

Authors' address:

Zakład Hydrologii

Instytut Geografii Fizycznej

Wydział Geografii i Studiów Regionalnych

Krakowskie Przedmieście 30, 00-927 Warszawa

Poland

e-mail:m.oksiuta@uw.edu.pl

e-mail: msgutryk@uw.edu.pl 